\title{
PENGARUH STRUKTUR MODAL, UKURAN PERUSAHAAN DAN KEPUTUSAN INVESTASI TERHADAP NILAI PERUSAHAAN
}

\author{
Rossabela Dwita, Kurniawan \\ Fakultas Ekonomi, Bisnis dan Ilmu Sosial, Universitas Matana \\ E-mail: kurniawan@matanauniversity.ac.id
}

\begin{abstract}
The purpose of this research was to determine the effect of Capital Structure measured using debt to assets ratio (DAR), firm size measured using total assets and investment decisions measured using price earnings ratio (PER) to firm value measured using price book value (PBV). in financial sector companies listed on the Indonesia Stock Exchange (IDX) period 2013-2016.

The type of research was causal research. The population in this research is financial sector companies listed on the Indonesia Stock Exchange (IDX) period 2013-2016.. Sampling technique that used in this study was purposive sampling technique. Of the population of 95 financial sector companies obtained Sample amounted to 49 companies of the financial sector listed on the Indonesia Stock Exchange in 2013-2016, so that the data analyzed research amounted to 196 observations. Data analysis techniques use multiple linear regression.

Based on the results of this study indicate that the Capital Structure has a negative and significant effect on the Company Value with $t$ value of -3.128 and the significance value smaller than 0.05 is 0.002 . The size of the company has a positive effect on the value of the company with a value of t arithmetic of 3.524 and the value of significance smaller than 0.05 is 0.001. Investment Decision has a positive effect on the company's value with $t$ value of 5.914 and significance value smaller than 0.05 ie 0.000 .
\end{abstract}

Keywords : Investment Decision, Company Size, Capital Structure, Value Company.

\section{Pendahuluan}

Tujuan berdirinya suatu perusahan terlebih lagi perusahaan yang sudah go public dimana sahamnya sudah tercatat pada Bursa Efek Indonesia (BEI) memiliki banyak tujuan salah satunya untuk memakmurkan pemilik atau pemegang saham serta memaksimalkan nilai perusahaan yang tercermin pada harga sahamnya. Nilai perusahaan merupakan harga yang akan dibayarkan oleh calon pembeli ketika perusahaan itu dijual, semakin tinggi nilai suatu perusahaan maka semakin besar tingkat kemakmuran yang didapat oleh pemilik pemegang saham (Husnan dan Pudjiastuti, 2006). Faktanya perusahaan tidak selalu mengalami peningkatan nilai perusahaan yang dibuktikan dari beberapa fenomena yang terjadi seperti sektor industri dan sektor keuangan telah mengalami penurunan di tahun 2013. Sektor industri (industri dasar dan kimia) yang melemah 2,63\% yang di sebabkan oleh impor serta harga jual produknya di pengaruhi faktor global. Sektor keuangan merosot hingga 2,21\% hingga akhir 2013 yang di sebabkan oleh kenaikan suku bunga acuan atau BI Rate. Analis PT First Asia Capital, David Sutyanto melihat kenaikan suku bunga menjadi 7,5\% memberi tekanan sektor keuangan khususnya perbankan dan membuat potensi pertumbuhan kredit melambat hingga akhir tahun 2013 (sumber:www.bisnis.liputan6.com 3 Desember 2013).

Menurut Trade off Theory menyatakan bahwa peningkatan rasio hutang pada struktur modal akan meningkatkan nilai perusahaan. Dengan demikian, teori tersebut menjelaskan 
bahwa ketika stuktur modal berada diatas target titik optimal maka setiap peningkatan hutang akan menurunkan nilai perusahaan. Sebaliknya ketika struktur modal berada dibawah target titik optimal maka setiap peningkatan hutang akan menaikkan nilai perusahaan (Avriansyah, 2013).

Ukuran perusahaan dianggap mampu mempengaruhi nilai perusahaan (Putra dan Lestari, 2016). Semakin besar ukuran perusahaan maka perusahaan semakin transparan dalam mengungkapkan kinerja perusahaan kepada pihak luar, dengan demikian perusahaan semakin mudah mendapatkan pinjaman karena semakin dipercaya oleh kreditur. Oleh karena itu, semakin besar ukuran perusahaan, aset yang didanai dengan hutang akan semakin besar pula (Aditama, 2015).

Penelitian yang dilakukan oleh Sudarsono (2015) menyebutkan bahwa keputusan investasi merupakan salah satu fungsi dari manajemen keuangan perusahaan yang akan tercermin pada sisi aset perusahaan sehingga mempengaruhi struktur kekayaan perusahaan. Keputusan investasi penting bagi perusahaan karena melalui kegiatan investasi, perusahaan dapat mencapai tujuan perusahaan yaitu memaksimumkan kemakmuran pemegang saham. Penelitian ini mengembangkan penelitian yang telah dilakukan oleh Robinhot Gultom, Agustina dan Sri Widia Wijaya pada tahun 2013. Dimana penelitian sebelumnya menganalisis faktor-faktor yang mempengaruhi nilai perusahaan pada perusahaan farmasi di Bursa Efek Indonesia (BEI) yang memiliki variabel independen diantaranya struktur modal, likuiditas, ukuran perusahaan dan profitabilitas. Penelitian tersebut menguji sejauh mana faktor-faktor yang dianalisis tersebut memmengaruhi nilai perusahaan.

Penelitian ini memiliki perbedaan dengan penelitian sebelumnya. Adapun perbedaan penelitian ini dengan penelitian sebelumnya yaitu penelitian sebelumnya menggunakan perusahaan farmasi yang terdaftar di Bursa Efek Indonesia (BEI) sebagai populasi lalu juga sampel sedangkan dalam penelitian ini menggunakan sampel yang berbeda yakni perusahaan sektor keuangan. Alasan menjadikan perusahaan sektor keuangan menjadi sampel karena didalam penelitian sebelumnya menyarankan untuk mencari sektor lain sebagai sampel yang akan diteliti selain itu sektor keuangan sangat jarang diteliti oleh peneliti peneliti terdahulu dimana sektor keuangan merupakan kelompok perusahaan industri jasa yang sudah masuk dalam perusahaan publik yang sudah terdaftar di Bursa Efek Indonesia dan dibagi menjadi beberapa sub sektor.

Penelitian mengenai nilai perusahaan juga telah dilakukan oleh beberapa peneliti, antara lain Sudarsono (2015) yang dalam penelitiannya memberikan hasil bahwa struktur modal yang diukur menggunakan DER tidak memiliki pengaruh terhadap nilai perusahaan, sedangkan Keputusan Investasi yang diukur menggunakan Earning Per Share (EPS) berpengaruh negatif signifikan terhadap nilai perusahaan. Hal ini bertentangan dengan penelitian yang dilakukan oleh Gayatri dan Mustandra (2016) yang mengatakan bahwa Struktur modal dan keputusan investasi berpengaruh positif signifkan terhadap nilai perusahaan. Penelitian lainnya yang dilakukan oleh Rahmawati dan Sulasmiyati (2015) memberikan hasil bahwa Keputusan Investasi berpengaruh signifikan dengan arah positif, Struktur modal berpengaruh signifikan dengan arah negatif, dan Ukuran perusahaan tidak berpengaruh signifikan terhadap Nilai Perusahaan. Hal ini bertentangan dengan penelitian yang dilakukan oleh Endarmawan (2014), dimana Keputusan investasi tidak berpengaruh terhadap nilai perusahaan, dan Noor (2016). Dimana ukuran perusahaan berpengaruh secara positif terhadap nilai perusahaan.

Berdasarkan uraian diatas, rumusan masalah penelitian ini, yaitu : (a). Apakah struktur modal memengaruhi nilai perusahaan pada perusahaan sektor keuangan yang listing di bursa efek indonesia tahun 2013-2016? (b). Apakah ukuran perusahaan memengaruhi nilai perusahaan pada perusahaan sektor keuangan yang listing di bursa efek indonesia tahun 2013-2016? (c). Apakah keputusan investasi memengaruhi nilai perusahaan pada perusahaan 
sektor keuangan yang listing di bursa efek indonesia tahun 2013-2016?

\section{Tinjauan Literatur dan Pengembangan Hipotesis}

\section{Teori sinyal}

Brigham dan Houston (2014) menjelaskan bahwa teori sinyal merupakan suatu tindakan yang diambil oleh manajemen perusahaan untuk memberikan petunjuk kepada investor tentang bagaimana manajemen menilai prospek perusahaan tersebut. Atas dasar pendapat itu dapat disimpulkan bahwa teori sinyal menjelaskan bahwa perusahaan mempunyai dorongan untuk memberikan informasi laporan keuangan pada pihak eksternal. Profesor Franco Modigliani dan Merton Miller (selanjutnya disebut MM) berasumsi bahwa setiap orang baik investor maupun manajer memiliki informasi yang sama tentang prospek suatu perusahaan. Hal ini disebut dengan informasi simetris (symetric information).

Tetapi, realitanya manajer sering kali memiliki informasi yang lebih baik dibandingkan dengan investor luar yang disebut sebagai informasi asimetris (asymmetric information). Kurangnya informasi bagi pihak investor luar mengenai perusahaan menyebabkan mereka melindungi diri dengan memberikan harga yang rendah untuk perusahaan (Brigham dan Houston, 2014). Perusahaan dapat meningkatkan nilai perusahaan dengan mengurangi informasi asimetri. Salah satu cara untuk mengurangi informasi asimetri adalah dengan memberikan sinyal pada pihak luar (Gunawan, 2016). Signaling theory juga memperlihatkan dimana perusahaan yang memiliki ukuran yang besar menunjukkan perusahaan mengalami perkembangan, selain itu ukuran perusahaan yang besar menunjukkan kondisi yang stabil terutama di dalam return pengembalian saham untuk investor lebih tinggi. Hal ini akan direspon positif oleh investor dan membuat harga saham perusahaan meningkat sehingga akan meningkatkan nilai perusahaan (Aditama, 2015).

\section{Theory of firm}

Teori ini menyatakan maksud atau tujuan utama perusahaan adalah untuk memaksimumkan kekayaan atau nilai perusahaan (Aditama, 2015). Harga saham yang tinggi mencerminkan nilai perusahaan juga tinggi. Harga saham merupakan harga yang terjadi pada saat saham diperdagangkan di pasar (Rachman, 2016). Nilai perusahaan yang dibentuk melalui indikator nilai pasar saham sangat dipengaruhi oleh peluang-peluang investasi. Adanya peluang investasi dapat memberikan sinyal positif tentang pertumbuhan perusahaan dimasa yang akan datang, sehingga akan meningkatkan harga saham, dengan meningkatnya harga saham maka nilai perusahaan pun akan meningkat (Aditama, 2015).

\section{Teori MM (Profesor Franco Modigliani dan Merton Miller)}

Teori MM membuktikan bahwa nilai suatu perusahaan seharunya tidak dipengaruhi oleh struktur modalnya. Dengan kata lain, menunjukan bahwa bagaimana cara perusahaan mendanai operasinya tidak memiliki pengaruh, sehingga struktur modal adalah sesuatu yang tidak relevan (Brigham dan Houston, 2014).

\section{Pecking Order Theory}

Teori ini berdasarkan atas informasi asimetrik (asymmetric information) yang menunjukan bahwa manajemen mempunyai informasi yang lebih besar tentang perusahaan (prospek, risiko dan nilai perusahaan) dibanding para pemilik modal. Karena manajemenlah yang mengambil keputusan-keputusan perusahaan hingga menyusun berbagai rencana perusahaan. Informasi asimetrik ini mempengaruhi pilihan antara sumber dana internal atau dana eksternal, dan antara penerbitan hutang baru atauk ekuitas baru. teori ini juga menjelaskan mengapa perusahaan akan menentukan hirarki sumber dana yang paling disukai. 
Maka investasi akan dibiayai dengan cara internal terlebih dahulu yaitu retained earnings kemudian baru diikuti oleh penerbitan hutang baru dan terakhir dengan penerbitan ekuitas baru.

\section{Trade-off Theory}

Trade-off Theory yang disebutkan oleh (Dewi dan Wirajaya, 2013) menyebutkan bahwa Perusahaan akan berhutang sampai pada tingkat utang tertentu, dimana penghematan pajak (tax shields) dari tambahan hutang sama dengan biaya kesulitan keuangan (financial distress). Biaya kesulitan keuangan (financial distress) adalah biaya kebangkrutan (bankruptcy costs) atau reorganization, dan biaya keagenan (agency costs) yang meningkat akibat dari turunnya kredibilitas suatu perusahaan. Trade-off theory dalam menentukan struktur modal yang optimal memasukkan beberapa faktor antara lain pajak, biaya keagenan (agency costs) dan biaya kesulitan keuangan (financial distress) tetapi tetap mempertahankan asumsi efisiensi pasar dan symmetric information sebagai imbangan dan manfaat penggunaan utang. Sejauh manfaat lebih besar penambahan hutang masih diperkenankan. Apabila pengorbanan karena penggunaan hutang sudah lebih besar, maka tambahan hutang sudah tidak diperbolehkan.

\section{Pengaruh Struktur Modal Terhadap Nilai Perusahaan}

Trade-off theory menjelaskan bahwa jika posisi struktur modal berada di bawah titik optimal maka setiap penambahan hutang akan meningkatkan nilai perusahaan. Sebaliknya, jika setiap posisi struktur modal berada di atas titik optimal maka setiap penambahan hutang akan menurunkan nilai perusahaan. Oleh karena itu, dengan asumsi titik target struktur modal optimal yang belum tercapai, maka berdasarkan trade-off theory memprediksi adanya hubungan yang positif terhadap nilai perusahaan (Dewi dan Wirajaya, 2013). Prediksi ini terbukti didalam penelitian yang dilakukan oleh Avriansyah (2013), Gayatri dan Mustanda (2014) dan Tunnisa (2016) bahwa struktur modal memiliki pengaruh yang positif terhadap nilai perusahaan, dan dalam penelitian Dewi dan Wirajaya (2013) dan Rahmawati et,al (2015) membuktikan bahwa struktur modal memiliki pengaruh negatif terhadap nilai perusahaan. Namun, hal ini tidak terbukti dalam penelitian yang dilakukan oleh Gultom et,al (2013), Sari et,al (2013), Sudarsono (2015) dan Anisyah dan Purwahandoko (2017) yang menyatakan bahwa struktur modal tidak memiliki pengaruh terhadap nilai perusahaan.

H1 : Struktur Modal Berpengaruh Positif Terhadap Nilai Perusahaan

\section{Pengaruh Ukuran Perusahaan Terhadap Nilai Perusahaan}

Perusahaan dengan aset yang besar umumnya merupakan perusahaan yang leading di industrinya (Noor, 2016). Besarnya skala perusahaan akan direspon dengan peningkatan harga saham perusahaan yang mengakibatkan peningkatan nilai perusahaan (Nurminda et,al, 2017). Dewi dan Wirajaya (2013) dalam jurnal penelitiannya menyebutkan juga bahwa ukuran perusahaan merupakan salah satu indikasi mengukur kinerja suatu perusahaan. Dalam penelitian yang dilakukan oleh Gultom et,al (2013) ukuran perusahaan dibuktikan tidak berpengaruh terhadap nilai perusahaan. Sama halnya dengan penelitian yang dilakukan oleh Dewi dan Wirajaya (2013), Arviansyah (2013) dan Rahmawati et,al (2015). Namun, dalam penelitian yang dilakukan oleh Aditama (2015) membuktikan bahwa ukuran perusahaan berpengaruh positif terhadap nilai perusahaan. hal ini dibuktikan juga didalam penelitian yang dilakukan oleh Putra dan Lestari (2016), Noor (2016) dan Anisyah dan Purwohandoko (2017). Untuk menguatkan penelitian sebelumnya, peneliti berasumsi untuk memberikan hipotesis bahwa ukuran perusahaan berpengaruh positif terhadap nilai perusahaan.

H2 : Ukuran Perusahaan Berpengaruh Positif Terhadap Nilai Perusahaan 


\section{Pengaruh Keputusan Investasi Terhadap Nilai Perusahaan}

Cahyono dan Sulistyawati (2016) menyebutkan bahwa nilai perusahaan yang dibentuk melalui indikator nilai pasar saham sangat dipengaruhi oleh peluang-peluang investasi. Hal ini berarti nilai perusahaan semata-mata ditentukan oleh keputusan investasi. Pendapat tersebut sejalan di dalam penelitian yang dilakukan oleh Gayatri dan Mustanda (2014), Ani (2016) dan juga penelitian yang dilakukan oleh Rahmawati et,al (2015) yang menyatakan bahwa keputusan investasi berpengaruh signifikan ke arah positif sedangkan Sudarsono (2015) didalam penelitiannya menyatakan bahwa keputusan investasi berpengaruh signifikan ke arah negatif. Setiani (2011) menyatakan bahwa keputusan investasi tidak berpengaruh signifikan dan arah negatif. Hal ini sejalan dengan penelitian yang dilakukan Endarmawan (2014) bahwa keputusan investasi tidak berpengaruh signifikan .

H3 : Keputusan Investasi Berpengaruh Positif Terhadap Nilai Perusahaan

\section{Metode Penelitian}

Desain penelitian ini termasuk jenis penelitian kausal, yaitu penelitian yang bertujuan untuk menguji hipotesis tentang pengaruh satu atau beberapa variabel (variabel independen) terhadap variabel lainnya (variabel dependen). Berdasarkan jenis datanya, penelitian ini tergolong penelitian kuantitatif yaitu penelitian yang menggunakan data berbentuk angka.

Data yang digunakan pada penelitian ini merupakan data sekunder. Sumber data yang digunakan adalah berasal dari laporan keuangan perusahaan sektor keuangan yang listing di Bursa Efek Indonesia (BEI) tahun 2013-2016.

Variabel dependen dalam penelitian ini adalah Nilai Perusahaan. Nilai perusahaan diproksikan dengan price to book value (PBV). PBV merupakan hasil perbandingan antara harga saham dengan nilai buku saham. Variabel independen yang digunakan di dalam penelitian ini adalah Struktur Modal, Ukuran Perusahaan dan Keputusan Investasi. Struktur modal dalam penelitian ini diproksikan menggunakan Debt to Assets Ratio (DAR) dengan melihat perbandingan antara total utang dengan total aset. ukuran perusahaan diukur menggunakan total aset. keputusan investasi diukur menggunakan Price Earning Ratio (PER). PER menunjukkan perbandingan antara harga per lembar saham dengan labanya. Pengambilan sampel dilakukan dengan metode purposive sampling yaitu teknik pengumpulan sampel berdasarkan pertimbangan kriteria tertentu.

Adapun kriteria yang digunakan antara lain :

a. Perusahaan yang dipilih sebagai sampel adalah perusahaan Sektor keuangan yang sudah listing di BEI pada tahun 2013- 2016.

b. Perusahaan sektor keuangan yang mencantumkan data secara lengkap selama tahun 2013-2016

c. Perusahaan sektor keuangan yang menghasilkan angka positif pada PER, PBV dan total aktiva.

Berdasarkan kriteria sampel di atas jumlah sampel yang didapatkan dari hasil pengamatan pada penelitian ini berjumlah 49 perusahaan. Jumlah periode pengamatan yang digunakan pada penelitian ini selama 4 tahun. Sehingga jumlah data yang digunakan pada penelitian ini sebanyak 196 data penelitian atau observasi.

\section{Hasil dan Pembahasan}

Berdasarkan purposive sampling jumlah sampel yang didapatkan dari hasil pengamatan pada penelitian ini berjumlah 49 perusahaan. Jumlah periode pengamatan yang digunakan pada penelitian ini selama 4 tahun. Sehingga jumlah data yang digunakan pada penelitian ini sebanyak 196 data penelitian. Analisis statistik deskriptif dalam penelitian ini 
meliputi mean, minimum, maximum, dan standar deviasi. Pengolahan data untuk analisis deskriptif ini menggunakan program IBM SPSS Statistic 24. Deskripsi data masing-masing variabel secara rinci dapat dilihat dalam tabel berikut:

Tabel 4.1 Hasil Uji Statistik Deskriptif

Descriptive Statistics

\begin{tabular}{|l|c|c|c|l|c|}
\hline & $\mathbf{N}$ & $\begin{array}{l}\text { Minimu } \\
\boldsymbol{m}\end{array}$ & $\begin{array}{l}\text { Maxi } \\
\text { mum }\end{array}$ & Mean & $\begin{array}{c}\text { Std. } \\
\text { Deviation }\end{array}$ \\
\hline SM & 196 &, 00 &, 93 &, 6876 &, 25552 \\
\hline $\mathbf{U P}$ & 196 & $\begin{array}{c}46702,0 \\
0\end{array}$ & $\begin{array}{l}60389 \\
6009\end{array}$ & $\begin{array}{l}91233832, \\
53\end{array}$ & 197743293,2 \\
\hline $\mathbf{K I}$ & 196 & 0,18 & 152,07 & 19,1654 & 23,83537 \\
\hline $\mathbf{N P}$ & 196 & 0,11 & 14,92 & 1,6122 & 1,81948 \\
\hline $\begin{array}{l}\text { Valid N } \\
\text { (listwise) }\end{array}$ & 196 & & & & \\
\hline
\end{tabular}

Sumber : Data diolah SPSS, 2018

Uji asumsi klasik dilakukan dengan menggunakan analisis regresi berganda terhadap variabel independen dan variabel dependen. Uji normalitas bertujuan untuk menguji apakah dalam model regresi dari variabel terikat dan variabel bebas dalam penelitian ini mempunyai distribusi data yang normal atau tidak. Model regresi yang baik adalah distribusi data normal atau mendekati normal.

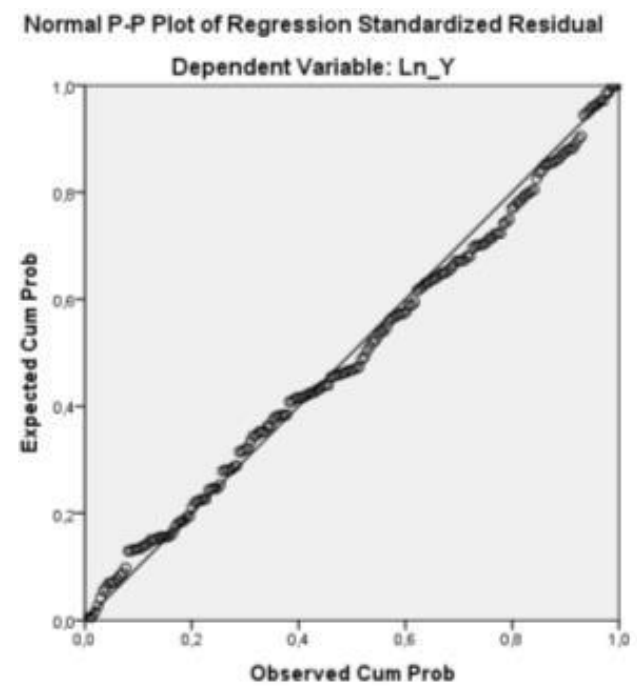

Sumber : Data diolah SPSS, 2018

Gambar 4.1 Grafik Normal P-P Plot 
Hasil uji normalitas juga dapat dilihat pada diagram histogram pada gambar 4.2 berikut ini:

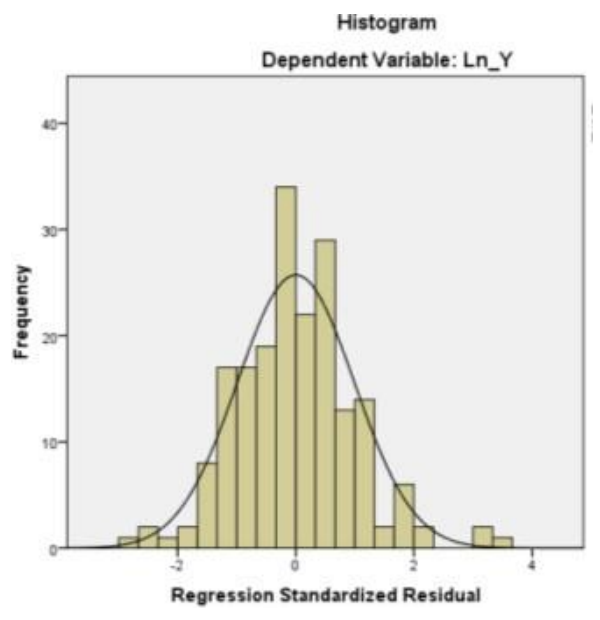

Sumber : Data diolah SPSS, 2018

Gambar 4.2 Histogram Normal P-P Plot

Berdasarkan Gambar 4.2 di atas, dapat ditunjukkan bahwa data telah terdistribusi secara normal.

Uji multikolonieritas bertujuan untuk menguji apakah model regresi ditemukan adanya korelasi antar variabel bebas (independen). Model regresi yang baik seharusnya tidak terjadi korelasi diantara variabel independen. Nilai yang digunakan untuk menunjukkan adanya multikolonieritas adalah nilai Tolerance $\leq 0.10$ atau sama dengan nilai Variance Inflation Factor (VIF) $\geq 10$. Jika nilai Tolerance $\geq 0.10$ atau sama dengan nilai Variance Inflation Factor (VIF) $\leq 10$ maka tidak terdapat multikolonieritas antar variabel bebas. Hasil uji multikolinieritas dapat dilihat pada tabel berikut:

Tabel 4.2 Hasil Uji Multikolinearitas

\begin{tabular}{|c|c|c|c|}
\hline \multirow{2}{*}{ Variabel } & \multicolumn{2}{|c|}{ Perhitungan } & \multirow{2}{*}{ Keterangan } \\
\cline { 2 - 3 } & Tolerance & VIF & \\
\hline $\begin{array}{c}\text { Struktur } \\
\text { Modal }\end{array}$ & 0,480 & 2.084 & $\begin{array}{c}\text { Tidak terjadi } \\
\text { Multikolinearitas }\end{array}$ \\
\hline $\begin{array}{c}\text { Ukuran } \\
\text { Perusahaan }\end{array}$ & 0,523 & 1,911 & $\begin{array}{c}\text { Tidak terjadi } \\
\text { Multikolinearitas }\end{array}$ \\
\hline $\begin{array}{c}\text { Keputusan } \\
\text { Investasi }\end{array}$ & 0,883 & 1,133 & $\begin{array}{c}\text { Tidak terjadi } \\
\text { Multikolinearitas }\end{array}$ \\
\hline
\end{tabular}

a. Dependent Variable : Nilai Perusahaan

b. Sumber : Data diolah SPSS, 2018

Uji heteroskedastisitas bertujuan untuk menguji apakah dalam model regresi terjadi ketidaksamaan variance dari residual satu pengamatan ke pengamatan yang lain. Untuk mendeteksi ada atau tidaknya heteroskedastisitas dilakukan dengan melihat ada atau tidaknya pola tertentu pada grafik scatterplot antara SRESID dan ZPRED. Jika terdapat pola tertentu seperti titik-titik yang ada membentuk suatu pola tertentu yang teratur (bergelombang, melebar kemudian menyempit), maka terjadi heterokedastisitas. Sebaliknya jika tidak terdapat pola yang jelas serta titik-titik menyebar di atas dan di bawah angka 0 (nol) pada sumbu Y, maka tidak terjadi heterokedastisitas. 


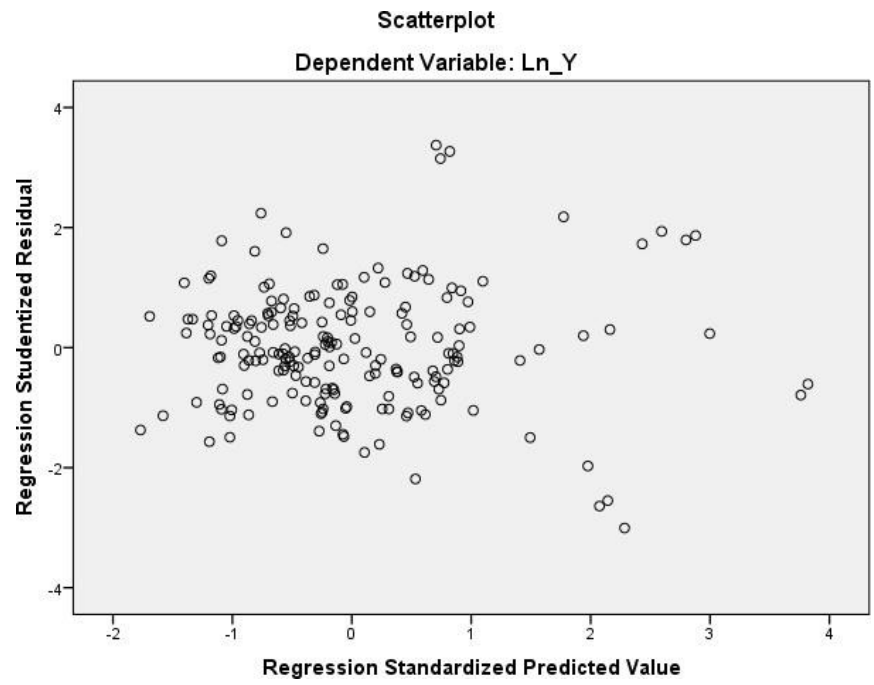

Sumber : Data diolah SPSS, 2018

\section{Gambar 4.4 Scatterplot Sesudah Transformasi}

Pada persamaan regresi linear berganda dalam model ini tidak ada gejala atau tidak terjadi heteroskedastisitas.

Uji autokorelasi bertujuan untuk menguji apakah dalam suatu model regresi ditemukan adanya autokorelasi dalam analisis regresi. Untuk mendeteksi ada atau tidaknya autokorelasi, maka dapat dilakukan dengan melihat nilai Durbin-Watson. Regresi yang bebas dari autokorelasi memiliki nilai Durbin-Watson harus memenuhi syarat berada diantara angka -2 dan +2 . Berikut ini adalah tabel yang menunjukkan hasil uji autokorelasi. Koefisien determinasi atau $\mathrm{R}$ Square $\left(\mathrm{R}^{2}\right)$ pada intinya digunakan untuk mengukur seberapa jauh kemampuan model dalam menerangkan variasi variabel dependen. Apabila nilai $\mathrm{R}^{2}$ kecil (mendekati nol) berarti kemampuan variabel independen dalam menjelaskan variabel dependen sangat terbatas. Nilai $\mathrm{R}^{2}$ yang mendekati satu berarti variabel-variabel independen memberikan hampir semua informasi yang dibutuhkan untuk memprediksi variabel dependen. hasil uji autokolerasi dengan uji durbin-watson dan hasil uji koefisien determinasi yang dilakukan dengan ibm spss statistics 24 dapat dilihat pada tabel berikut:

Tabel 4.3

Hasil Uji Autokolerasi dengan Uji Durbin- Watson dan Hasil Uji Koefisien Determinasi Model Summary

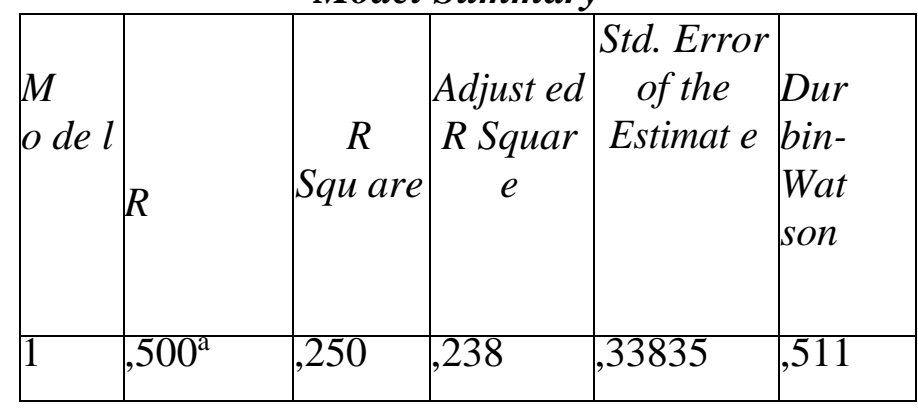

a. Predictors: (Constant), Keputusan Investasi, Ukuran Perusahaaan, Struktur Modal

b. Dependent Variable: Ln_Y Sumber : Data diolah SPSS, 2018

Berdasarkan tabel 4.3 diatas dapat diketahui bahwa hasil uji autokorelasi pada nilai Durbin-Watson adalah 0,511 . Nilai yang dihasilkan tersebut berada diantara angka -2 dan +2 
sehingga dapat disimpulkan bahwa data yang digunakan di dalam penelitian ini bebas dari autokorelasi dan nilai $\mathrm{R}^{2}$ sebesar 0,250 mempunyai arti bahwa variabel dependen mampu dijelaskan oleh variabel independen sebesar $25 \%$, dengan kata lain $25 \%$ nilai perusahaan mampu dijelaskan variabel struktur modal, ukuran perusahaan, dan keputusan investasi sedangkan $75 \%$ dijelaskan oleh faktor lain yang tidak di masukkan ke dalam penelitian ini.

Regresi linier berganda bertujuan untuk menguji pengaruh dua atau lebih variabel independen terhadap variabel dependen. Analisis regresi berganda dilakukan dengan menggunakan program IBM SPSS Statistic 24. Hasil uji regresi berganda dapat dilihat pada tabel berikut:

Tabel 4.5 Hasil Uji Analisis Regresi Linier Berganda

Coefficients $^{\mathbf{a}}$

\begin{tabular}{|c|c|c|c|c|c|}
\hline \multirow{2}{*}{ Mode l } & \multicolumn{2}{|c|}{$\begin{array}{c}\text { Unstandardized } \\
\text { Coefficients }\end{array}$} & \multirow{2}{*}{$\begin{array}{c}\begin{array}{c}\text { Standar dized } \\
\text { Coeffici } \\
\text { ents }\end{array} \\
\text { Beta }\end{array}$} & \multirow{2}{*}{$\mathrm{T}$} & \multirow{2}{*}{ Sig. } \\
\hline & B & $\begin{array}{c}\text { Std. } \\
\text { Error }\end{array}$ & & & \\
\hline $\begin{array}{l}1 \\
\text { (Cons tant) } \\
\end{array}$ & 0,494 & 0,143 & & 3,459 & 0,001 \\
\hline SM & 0,651 & 0,202 & $-0,294$ & $\begin{array}{r}- \\
3,218\end{array}$ & 0,002 \\
\hline UP & $\begin{array}{r}9,789 \\
\text { E-10 }\end{array}$ & 0,000 & 0,308 & 3,524 & 0,001 \\
\hline KI & 0,012 & 0,0002 & 0,398 & 5,914 & 0,000 \\
\hline
\end{tabular}

Sumber : Data diolah SPSS, 2018

Berdasarkan perhitungan regresi linier berganda yang ditunjukkan dari tabel 4.5 diatas dapat dirumuskan suatu persamaan regresi untuk mengetahui pengaruh struktur modal, ukuran perusahaan dan keputusan investasi terhadap nilai perusahaaan sebagai berikut:

$$
Y=0,494-0,651 X 1+9,789 E-10 X 2+0,012 X 3+e
$$

Uji $F$ dilakukan untuk menguji secsara keseluruhan (simultan) pengaruh variabel independen terhadap variabel dependen. Apabila nilai $F$ hitung $>F$ tabel maka dapat disimpulkan bahwa model regresi sudah layak untuk digunakan sebagai model regresi dalam penelitian karena variabel independen mampu menjelaskan variabel dependen secara bersama-sama dan sebaliknya. Hasil uji $F$ dapat dilihat pada Tabel 4.6 berikut:

Tabel 4.6 Hasil Uji Statistik F ANOVA ${ }^{a}$

\begin{tabular}{|l|r|r|r|r|l|}
\hline Model & $\begin{array}{l}\text { Sum of } \\
\text { Squares }\end{array}$ & Df & $\begin{array}{l}\text { Mean } \\
\text { Square }\end{array}$ & F & Sig. \\
\hline $\begin{array}{l}\text { Regress } \\
\text { ion }\end{array}$ & 7,159 & 3 & 2,386 & 20,8 &, $000^{\mathrm{b}}$ \\
\hline $\begin{array}{l}\text { Residu } \\
\text { al }\end{array}$ & 21,523 & 188 &, 114 & & \\
\hline \multicolumn{1}{|c|}{ Total } & 28,682 & 191 & & & \\
\hline
\end{tabular}


a. Dependent Variable: Ln_Y

b. Predictors: (Constant), Keputusan Investasi, Ukuran Perusahaan, Struktur Modal

Sumber : Data diolah SPSS, 2018

Dari Tabel 4.6 dapat diketahui bahwa nilai $F$ hitung sebesar 20.843 dengan $F$ Tabel sebesar 2,42 sehingga $F$ hitung $>F$ Tabel $(20.843>2,42)$ dengan tingkat signifikansinya $0,000<0,05$. Hal ini berarti bahwa terdapat pengaruh yang signifikan secara bersama- sama antara semua variabel independen terhadap variabel dependen. Uji Statistik t digunakan untuk menunjukkan seberapa jauh pengaruh dan signifikansi satu variabel independen terhadap variabel dependen. Pengujian hasil regresi dilakukan dengan menggunakan uji-t pada derajat keyakinan 95\%. Hasil uji t variabel independen terhadap variabel dependen adalah sebagai berikut:

Tabel 4.7 Hasil Uji Statistik T

Coefficients $^{\mathbf{a}}$

\begin{tabular}{|l|r|r|r|r|r|}
\hline \multirow{4}{*}{ Mo del } & \multicolumn{2}{|l|}{$\begin{array}{l}\text { Unstandardized } \\
\text { Coefficients }\end{array}$} & $\begin{array}{l}\text { Standar } \\
\text { dized } \\
\text { Coeffici } \\
\text { ents }\end{array}$ & $\mathrm{t}$ & \multirow{2}{*}{ Sig. } \\
\cline { 2 - 5 } & $\mathrm{B}$ & $\begin{array}{l}\text { Std. } \\
\text { Error }\end{array}$ & Beta & & \\
\hline $\begin{array}{l}\text { (Co } \\
\text { nsta nt) }\end{array}$ & 0,494 & 0,143 & & 3,459 & 0,001 \\
\hline SM & $-0,651$ & 0,202 & $-0,294$ & 3,218 & 0,002 \\
\hline UP & $9,789 \mathrm{E}$ & 0,000 & 0,308 & 3,524 & 0,001 \\
\hline KI & 0,012 & 0,0002 & 0,398 & 5,914 & 0,000 \\
\hline
\end{tabular}

Sumber : Data diolah SPSS, 2018

Struktur Modal (SM) yang diproksikan dengan Debt to Assets Ratio (DAR) memiliki nilai t hitung sebesar $-3,218$ dengan signifikansi sebesar 0,002 . Nilai t hitung sebesar $-3,218$ dan nilai signifikansi lebih kecil dari $0,05(0,002<0,05)$ menunjukkan bahwa struktur modal berpengaruh negatif dan signifikan terhadap nilai perusahaan pada perusahaan sektor keuangan yang listing di Bursa Efek Indonesia pada tahun 2013-2016. Hasil ini sesuai dengan penelitian yang dilakukan oleh Dewi dan Wirajaya (2013) dan Rahmawati et,al (2015), dimana dalam penelitian tersebut membuktikan bahwa struktur modal memiliki pengaruh negatif terhadap nilai perusahaan.

Hasil penelitian ini juga sesuai dengan teori Modigliani dan Miller pada tahun 1963 yang menyatakan bahwa dengan memasukkan pajak penghasilan perusahaan, maka penggunaan hutang akan meningkatkan nilai perusahaan karena biaya bunga hutang adalah biaya yang mengurangi pembayaran pajak tetapi penelitian ini tidak selaras dengan temuan yang dilakukan oleh Arviansyah (2013), Gayatri dan Mustanda (2014) dan Tunnisa (2016) yang menyatakan bahwa struktur modal berpengaruh secara positif dan signifikan terhadap nilai perusahaan,

Ukuran Perusahaan (UP) yang diproksikan dengan Total aset memiliki nilai t hitung sebesar 3,524 dengan signifikansi sebesar 0,001. Nilai t hitung sebesar 3,524 dan nilai 
signifikansi lebih kecil dari $0,05(0,001<0,05)$ menunjukkan bahwa ukuran perusahaan berpengaruh positif dan signifikan terhadap nilai perusahaan pada perusahaan sektor keuangan yang listing di Bursa Efek Indonesia (BEI) pada tahun 2013-2016. Hasil ini sesuai dengan penelitian yang dilakukan oleh Aditama (2015) dan Noor (2016), dimana dalam penelitian tersebut membuktikan bahwa ukuran perusahaan memiliki pengaruh positif terhadap nilai perusahaan.

Hasil penelitian ini juga terbukti pada penelitian yang dilakukan oleh Anisyah dan Purwahandoko (2017), Hal ini sejalan dengan signaling theory yang menyatakan bahwa perusahaan dapat mengkomunikasikan prospek pertumbuhan yang baik bagi perusahaan dimasa depan dengan menggunakan utang. Sebab utang dapat menjadi sinyal positif bagi investor luar, sehingga investor luar dapat yakin dan percaya bahwa prospek perusahaan dimasa depan akan baik.

Hasil penelitian serupa juga diungkapkan oleh Putra dan Lestari (2016) yang menyatakan bahwa ukuran perusahaan berpengaruh positif dan signifikan terhadap nilai perusahaan. Keputusan investasi yang diproksikan dengan Price Earnings Ratio (PER) memiliki nilai t hitung sebesar 5,914 dengan signifikansi sebesar 0,000. Nilai t hitung sebesar 5,914 dan nilai signifikansi lebih kecil dari $0,05(0,000<0,05)$ menunjukkan bahwa keputusan investasi berpengaruh positif dan signifikan terhadap nilai perusahaan pada perusahaan sektor keuangan yang listing di Bursa Efek Indonesia pada tahun 2013-2016, Hasil ini sesuai dengan penelitian yang dilakukan oleh Cahyono dan Sulistyawati (2016) Gayatri dan Mustanda (2014) dan Ani (2016), dimana dalam penelitian tersebut membuktikan bahwa keputusan investasi memiliki pengaruh positif terhadap nilai perusahaan.

Hasil penelitian yang dilakukan Rahmawati et,al (2015) juga membuktikan bahwa keputusan investasi yang diukur dengan PER mampu membuat nilai perusahaan ikut meningkat.

\section{SIMPULAN DAN SARAN}

\section{SIMPULAN}

Berdasarkan pendahuluan, kajian teori, pengolahan data terhadap 49 sampel perusahaan dengan menggunakan model regresi linier berganda, serta pembahasan yang telah dilakukan pada bab terdahulu, maka dapat ditarik kesimpulan sebagai berikut:

1. Struktur Modal yang diukur menggunakan DAR berpengaruh negatif dan signifikan terhadap nilai perusahaan pada perusahaan sektor keuangan yang listing di Bursa Efek Indonesia pada tahun 2013-2016. Hal ini ditunjukkan oleh nilai t hitung sebesar -3,218 dan signifikansi sebesar 0,002 <0,05, Berdasarkan hasil tersebut dapat disimpulkan bahwa setiap kenaikan struktur modal akan selalu diikuti dengan penurunan nilai perusahaan, begitu pula sebaliknya.

2. Ukuran Perusahaan yang diukur menggunakan total aset berpengaruh positif dan signifikan terhadap nilai perusahaan pada perusahaan sektor keuangan yang listing di Bursa Efek Indonesia pada tahun 2013-2016. Hal ini ditunjukkan oleh nilai t hitung sebesar 3,524 dan signifikansi sebesar 0,001 <0,05, Berdasarkan hasil tersebut dapat disimpulkan bahwa setiap kenaikan Ukuran Perusahaan akan selalu diikuti dengan peningkatan nilai perusahaan, begitu pula sebaliknya.

3. Keputusan Investasi yang diukur menggunakan PER berpengaruh positif dan signifikan terhadap nilai perusahaan pada perusahaan sektor keuangan yang listing di Bursa Efek Indonesia pada tahun 2013-2016. Hal ini ditunjukkan oleh nilai t hitung sebesar 5,914 dan signifikansi sebesar $0,000<0,05$, Berdasarkan hasil tersebut dapat disimpulkan bahwa setiap kenaikan Keputusan Investasi akan selalu diikuti dengan peningkatan nilai 
perusahaan, begitu pula sebaliknya.

4. Struktur Modal, Ukuran Perusahaan dan Keputusan Investasi secara bersama-sama berpengaruh positif dan signifikan terhadap Nilai Perusahaan. Hal ini dibuktikan dengan nilai $F$ hitung sebesar 20,843 dengan probabilitas sebesar 0,000 serta hasil koefisien R2 adalah 0,250 maka dapat disimpulkan bahwa seluruh variabel independen secara bersama-sama berpengaruh positif signifikan terhadap variabel dependen. Nilai probabilitas sebesar $0,000<0,05$ membuktikan bahwa Struktur Modal, Ukuran Perusahaan dan Keputusan Investasi secara bersama-sama berpengaruh signifikan terhadap Nilai Perusahaan. Nilai koefisien R2 sebesar 0,250 menunjukkan bahwa kontribusi seluruh variabel independen dalam menjelaskan variabel dependen adalah sebesar $25 \%$, sedangkan sisanya sebesar $75 \%$ dijelaskan oleh variabel lain yang tidak dimasukkan ke dalam penelitian ini.

\section{SARAN}

Berdasarkan hasil penelitian yang telah dikemukakan maka dapat dikemukakan beberapa saran sebagai berikut:

1. Bagi Investor

Dari hasil penelitian ini, maka investor dapat mempertimbangkan faktor struktur modal, ukuran perusahaan dan keputusan investasi karena semua faktor tersebut memiliki pengaruh yang signifikan terhadap nilai perusahaan pada perusahaan sektor keuangan yang listing di Bursa Efek Indonesia pada tahun 2013-2016. sehingga investor diharapkan akan dapat menentukan dimana investasi yang paling tepat untuk dilakukan.

2. Bagi Peneliti Selanjutnya

Dari hasil penelitian ini diharapkan peneliti selanjutnya dapat melakukan penelitian yang lebih lanjut berkaitan dengan faktor-faktor yang mempengaruhi nilai perusahaan. Dengan menambah periode penelitian yang lebih dari 5 tahun karena penelitian ini hanya mengambil jangka waktu 3 tahun yaitu dari tahun 2013 sampai dengan 2015, sehingga data yang diambil ada kemungkinan kurang mencerminkan kondisi perusahaan dalam jangka panjang. Penelitian ini hanya menggunakan perusahaan sektor keuangan sebagai objek penelitian, dan masih sangat banyak perusahaan yang dapat dijadikan sampel dalam penelitian ini, untuk itu bagi penelitian selanjutnya dapat menganti objek penelitian pada sektor atau indeks tertentu dan menambah variabel lain dalam penelitian seperti variabel kebijakan dividen, profitabilitas, leverage dan likuiditas. Selain itu, peneliti selanjutnya dapat menggunakan proksi lain untuk menghitung nilai perusahaan seperti Price Earning Ratio (PER) atau Tobin's Q.

3. Bagi Perusahaan

Perusahaan sebaiknya terus berusaha meningkatkan keputusan investasi dan ukuran perusahaan yang nantinya akan berpengaruh terhadap peningkatan nilai perusahaan. Dengan meningkatnya nilai perusahaan akan meningkatkan kesejahteraan pemegang saham dan akan menarik minat investor untuk berinvestasi pada perusahaan. Dalam meningkatkan nilai perusahaan perusahaan juga harus melihat struktur modal perusahaan karena berdasarkan hasil penelitian variabel struktur modal berpengaruh negatif signifikan terhadap nilai perusahaan yang berarti setiap peningkatan struktur modal menurunkan nilai perusahaan. Dengan demikian diharapkan perusahaan bisa menjaga nilai perusahaannya agar tidak turun dan terus meningkat dengan memfokuskan peningkatan kepada variabel yang memiliki pengaruh positif dan tetap memperhatikan variabel yang memiliki pengaruh negatif agar tidak terus meningkat dan menurunkan nilai perusahaan. 


\section{DAFTAR PUSTAKA}

Aditama, Fahad. (2015). Pengaruh Ukuran Perusahaan, Kepemilikan Institutional dan Pertumbuhan Penjualan Terhadap Nilai Perusahaan Dengan Kebijakan Hutang Sebagai Variabel Intervening Pada Perusahaan Manufaktur Yang Terdaftar di BEI. Jurusan Akuntansi Fakultas Ekonomi Universitas Negeri Semarang, Semarang.

Afzal, Arie. (2012). Pengaruh Keputusan Investasi, Keputusan Pendanaan dan Kebijakan Dividen Terhadap Nilai Perusahaan. Fakultas Ekonomika dan Bisnis Universitas Diponegoro, Semarang.

Ambarwati, Sri Dwi Ari. (2010). Manajemen Keuangan Lanjut. Edisi Pertama. Yogyakarta : Graha Ilmu.

Ani, Fitri. (2016). Pengaruh Keputusan Investasi Terhadap Nilai Perusahaan Jasa Perbankan Yang Terdaftar di Bursa Efek Indonesia. Program Studi Akuntansi Fakultas Ekonomi dan Bisnis Islam Universitas Islam Negeri Alauddin, Makassar.

Anisyah \& Purwahandoko. (2017). Pengaruh Profitabilitas, Leverage, Ukuran Perusahaan dan Struktur Modal Terhadap Nilai Perusahaan pada Sektor Pertambangan yang Terdaftar di Bursa Efek Indonesia Periode 2010-2015. Jurnal Manajerial Bisnis, 1(1).

Arviansyah, Yandri. (2013). Pengaruh Struktur Modal, Kinerja Keuangan Perusahaan, Pertumbuhan Perusahaan dan Ukuran Perusahaan Terhadap Nilai Perusahaan pada Perusahaan yang Terdaftar di Jakarta Islamic Index (JII) (Studi empiris pada perusahaan yang terdaftar di JII periode 2008-2011). Jurusan Akuntansi Fakultas Ekonomi dan Bisnis UIN Syarif Hidayatullah, Jakarta.

Azis, Rifandi Yoki. (2017). Pengaruh Keputusan Investasi , Kebijakan Dividen Dan Kebijakan Hutang Terhadap Nilai Perusahaan Manufaktur yang Terdaftar di BEI. Jurusan Manajemen Fakultas Ekonomi Universitas Negeri Yogyakarta.

Brigham, Eugene F \& Joel F. Houston. (2013). Dasar-Dasar Manajemen Keuangan Essentials of Financial Management. Buku kedua. Edisi Kesebelas. Jakarta: Salemba Empat.

Cahyono, Heri Setiyo \& Ardiani Ika Sulistyawati. (2016). Keputusan Investasi, Keputusan Pendanaan dan Kebijakan Dividen Sebagai Determinan Nilai Perusahaan. Akuisisi, 12(2).

Dewi, Ayu Sri Mahatma \& Ary Wirajaya. (2013). Pengaruh Struktur Modal Profitabilitas dan Ukuran Perusahaan pada Nilai Perusahaan. E- Jurnal Akuntansi Universitas Udayana. 4(2), 361-363.

Endarmawan, Yogy. (2014). Pengaruh Keputusan Investasi, Keputusan Pendanaan, dan Kebijakan Dividen terhadap Nilai Perusahaan. Artikel Ilmiah Mahasiswa.

Gayatri, Ni Luh Putu Rassri \& I Ketut Mustanda. (2014). Pengaruh Struktur Modal, Kebijakan Dividen dan Keputusan Investasi Terhadap Nilai Perusahaan. Jurnal. Fakultas Ekonomi dan Bisnis Universitas Udayana.

Ghozali, Imam. (2013). Aplikasi Analisis Multivariate Dengan Program IBM SPSS 21. Edisi Ketujuh. Semarang: Badan Penerbit Universitas Diponegoro.

Gultom, Robinhot, Agustina dan Sri Widia Wijaya. (2013). Analisis Faktor-Faktor Yang Mempengaruhi Nilai Perusahaan Pada Perusahaan Farmasi di Bursa Efek Indonesia. Jurnal Wira Ekonomi Mikroskil, 3(1), 51-53.

Gunawan, Rendy Maulana. (2016). Pengaruh Keputusan Investasi, Keputusan Pendanaan dan Kebijakan Dividen Terhadap Nilai Perusahaan Pada Perusahaan Kontruksi Yang Terdaftar di Bursa Efek Indonesia. Fakultas Ekonomi dan Bisnis, Universitas Lampung, Bandar Lampung.

Husnan, Suad \& Enny Pudjiastuti. (2006). Dasar- Dasar Manajemen Keuangan. Edisi Kelima. Jakarta: UPP STIM YKPN. 
Kasmir. (2010). Analisis Laporan Keuangan. Edisi Ketiga. Depok: Raja Grafindo Persada. PT.

Kerlinger, Fred. N \& Elazar J. Pedhazur. (1987). Korelasi dan Analisis Regresi Ganda. Diterjemahkan oleh: Drs. A. Taufiq. IR. Yogyakarta: Penerbit Nur Cahaya.

Martikarini, Nani, (2014). Pengaruh Profitabilitas, Kebijakan Hutang, dan Dividen terhadap Nilai Perusahaan Manufaktur yang Terdaftar di Bursa Efek Indonesia Periode 2009-

2011. Artikel. Fakultas Ekonomi Jurusan Akuntansi Universitas Gunadarma.

Noor, Fauzia Marwah. (2016). Pengaruh Profitabilitas dan Ukuran Perusahaan Terhadap Nilai Perusahaan (Studi Kasus Pada Perusahaan Makanan dan Minuman yang Terdaftar di Bursa Efek Indonesia Periode Tahun 2010-2014). Universitas Komputer Indonesia.

Nurminda, Aniela, Deannes Isynuwarhana \& Annisa Nurbaitti. (2017). Pengaruh Profitabilitas, Leverage, dan Ukuran Perusahaan Terhadap Nilai Perusahaan (Studi pada Perusahaan Manufaktur Sub Sektor Barang dan Konsumsi yang Terdaftar di Bursa Efek Indonesia Periode 2012-2015). e-Proceeding of Management. 4(1).

Prastuti, Ni Kadek Rai \& I Gede Merta Sudiartha. (2016). Pengaruh Struktur Modal, Kebijakan Dividen, dan Ukuran Perusahaan Terhadap Nilai Perusahaan Pada Perusahaan Manufaktur. E-Jurnal Manajemen Universitas Udayana. 5(3), 1573-1578.

Putra, AA Ngurah Dharma Adi \& Putu Vivi Lestari. (2016). Pengaruh Kebijakan Dividen, Likuiditas, Profitabilitas dan Ukuran Perusahaan Terhadap Nilai Perusahaan. E-Jurnal Manajemen Universitas Udayana, 5(7), 4048.

Rachman, Nur Aidha. (2016). Faktor-Faktor Yang Mempengaruhi Nilai Perusahaan Pada Sektor Industri Food And Beverages Yang Terdaftar di Bursa Efek Indonesia (BEI) Pada Tahun 2011- 2015. Jurusan Pendidikan Ekonomi Fakultas Ekonomi Universitas Negeri Yogyakarta, Yogyakarta.

Rahmawati, Amalia Dewi, Topowijono \& Sri Sulasmiyati. (2015). Pengaruh Ukuran Perusahaan, Profitabilitas, Struktur Modal dan Keputusan Investasi Terhadap Nilai Perusahaan (Studi pada Perusahaan Sektor Properti, Real Estate, dan Building Construction yang Terdaftar di Bursa Efek Indonesia (BEI) Periode 2010-2013). Jurnal Administrasi Bisnis (JAB), 23(2).

Rahmi, Fahla Amalina. (2014). Pengaruh Profitabilitas dan Struktur Modal Terhadap Nilai Perusahaan (Studi Empiris pada Perusahaan Sektor Agriculture yang Terdaftar di Bursa Efek Indonesia Periode 2010-2013). Fakultan Ekonomi Universitas Widyatama, Bandung.

Sari, Diah Manda, Emilia Gustini \& Lukita Tri Permata. (2016). Pengaruh Struktur Modal dan Kinerja Keuangan Terhadap Nilai Perusahaan Perbankan di Bursa Efek Indonesia. Jurnal Ilmiah Ekonomi Global Masa Kini, 7(3).

Setiani, Rury. (2011). Tingkat Suku Bunga Terhadap Nilai Perusahaan Pada Perusahaan Otomotif Yang Terdaftar di Bursa Efek Indonesia. Alumni Fakultas Ekonomi UNP.

Sudana, I Mad. (2011). Manajemen Keuangan Teori \& Praktik. Jakarta: Erlangga.

Sudarsono, Mahani Alfianti. (2015). Pengaruh Struktur Modal, Kebijakan Dividen, Keputusan Investasi, dan Profitabilitas Terhadap Nilai Perusahaan (Studi Pada Perusahaan Yang Efeknya Terdaftar di Daftar Efek Syariah Tahun 2011-2013). Jurusan Manajemen Fakultas Ekonomi Universitas Negeri Semarang.

Sugiyono. (2013). Metodologi Penelitian Kuantitatif, Kualitatif Dan R\&D. Bandung: Alfabeta.

Tunnisa, Fadhilah. (2016). Pengaruh Struktur Modal Terhadap Nilai Perusahaan Dengan Profitabilitas Sebagai Variabel Intervening Pada Perusahaan Manufaktur di Bursa Efek Indonesia. Fakultas Ekonomi dan Bisnis Islam UIN Alauddin, Makassar. 
Wibisono, D. (2013). Panduan Penyusunan Skripsi, Tesis \& Disertasi. Yogyakarta: Penerbit Andi.

http://www.tribunnews.com/. Diakses Pada Bulan Ferbruari 2018.

https://www.liputan6.com/bisnis/saham. Diakses Pada Bulan Februari 2018.

http://www.idx.co.id/perusahaan-tercatat/laporan-keuangan-dan-tahunan/. Diakses Pada Bulan Maret 2018.

http://www.idx.co.id/perusahaan-tercatat/aktivitas- pencatatan/. Diakses Pada Bulan Maret 2018. 